\title{
Editorial: The Vital Pedagogy of the New Coronavirus
}

\author{
Nicoletta Dentico ${ }^{1}$
}

Published online: 8 December 2020

(c) Society for International Development 2020

'The catastrophe will be triggered off by an unpredictable event [...] What only a few could see will instantly become evident to the many: the economy organized with the aim to live better has become the main obstacle to living well'. Ivan Illich, Conviviality

\section{The New Coronavirus in a Planet that Cannot Breathe}

After 10 months, the world remains trapped in the enigmatic suspension of COVID-19's viral waves. In February 2020, the new coronavirus pandemic struck the world with the biggest shock since the second World War. The health crisis, which had long been predicted yet arrived as an unexpected event, marks a watershed, a piercing time before and after that changes the route of the twenty-first century and our way of looking at it. The catastrophic pathogen is not a metaphor this time. It attacks the human body and disrupts the overall growth mechanism. Systems of global value chains have shuddered as factories have shut down and countries closed their borders. The 2001 attacks on the Twin Towers and the 2008 global financial crisis-the two shocks that occurred at the dawn of the new millennium-had surely sickened the world and led to a backlash of ethical and political questions, including around the state of emergency and its unprecedented exercise of power. They had poisoned societies with austerity measures and the expanded exclusion of social groups. Yet, the course of history had not ultimately changed the image of an integrated world economy. The value frame of globalization-despite its fragmentation-resisted the shockwave. The celebrated narrative of progress and prosperity remained dominant.

Things are different with the invisible, impalpable SARSCoV-2. The spill over this time comes from within. It evokes

Nicoletta Dentico ndentico@sidint.org

1 Society for International Development (SID), Rome, Italy what the French anthropologist Marcel Mauss referred to as a 'total social fact', an event that connects and unfolds its implications in the totality of society-the economic, legal, political and religious spheres. As Shiv Visvanathan warns us:

Nature has always inspired performances, magnificent narratives, whether it incarnates itself as a deluge an eclipse, or a virus. Whether it was the great flood, the ice age, or the bubonic plague, it has shaped history and controlled our imaginations. Of late, man has been con-temptuous of nature and read the medieval plague as a thing of the past, while it is an imagination that should continue to haunt us (Visvanathan 2020).

Nature's reaction this time reveals 'the dark clouds over a closed world', ${ }^{1}$ in the sense that the outbreak is not only the feverish spasm responding to the destruction of living ecosystems and wildlife encroachment, but also a response to the myths and falsehoods around the promised universal civilization of free markets and human rights. For the first time, a minuscule organism has paralyzed the ruthless patterns of the most technologically advanced human civilization. This had never happened on a global scale. 'Never, in the history of the IMF, have we witnessed the world economy coming to a standstill', declared the IMF managing director. ${ }^{2}$ All past oracles, all geopolitical creeds and social realities have been deeply shaken, nation states have become self-centered and, with the likes of US, Britain, India, China or Brazil, literally parochial, even punitive. The 'sovereign virus' has brought a paradigm to its end (Di Cesare 2020).

SARS CoV-2 attacks the physical body and proliferates in the respiratory tract. It takes away its breath, the very metonymy of existence. But that is one aspect of the story. The

\footnotetext{
${ }^{1}$ Pope Francis, Fratelli Tutti (Brothers All), Encyclical Letter of the Holy Father Francis on Fraternity and Social Friendship, chapter one, http://www.vatican.va/content/francesco/en/encyclicals/documents/ papa-francesco_20201003_enciclica-fratelli-tutti.html.

2 IMF, Opening Remarks by IMF Managing Director Kristalina Georgieva at the WHO Press Conference, 3 April 2020, https://www. imf.org/en/News/Articles/2020/04/03/tr040320-transcript-kristalina -georgieva-participation-world-health-organization-press-briefing.
} 
unknown virus, in fact, has assaulted the body of humankind, worn-out by decades of intolerable instability and the burning fire of inequalities. By throwing a merciless light on the social apartheid that features our time in the name of the unrestrained pursuit of profit, COVID-19 has revealed the asphyxiation of precarity capitalism (Azmanova 2020). The virus has produced an enigmatic suspension of capitalism's global hyper-activity and its pathogenesis; an unprecedented chain reaction that has led to the contraction of the economy and the abrupt interruption of an outgrowth with little purpose and no sense of measure. An impairment that Donatella Di Cesare describes well in her book:

Until yesterday, we could consider ourselves omnipotent in the midst of the rubble, the first and only ones also in our primacy of destruction. This primacy has been taken away by a superior and more destructive power. That it be a virus, a tiniest portion of organized material, makes the event all the more traumatic. Even the smallest creature can dethrone us, divest and unsaddle us. Who knows, life on earth may take new directions. But in the meantime, we need to acknowledge that we are not as omnipotent as we presumed. In fact, we are extremely vulnerable (Di Cesare 2020: 21-22).

Not only has human omnipotence been contagiously dethroned, but almost overnight the entire set of market orthodoxies that debilitated the world collapsed, to make space for the primacy of human health needs and the values of solidarity, in a remarkable display of care for people. COVID-19 has demonstrated to what extent the denial of health is enshrined in the very structures of global capitalism and it has illuminated to what extent these much-fetishized economic structures are a death machine for all living beings and the planet, in the systemic natural connection between the environment and its inhabitants, human and planetary health.

\section{Lost in Diseases: Reclaiming Health as a Common, Beyond COVID-19}

Our journal issue, inaugurating SID's engagement in the territory of global health, intends to stimulate a broad-based reflection about health justice and the politics of care, starting the conversation from the viewpoint of the global fragility that has long afflicted the lives of billions of people around the world, and yet remained concealed until COVID19 came to tear the veil. On the other hand, the origins of this virus and the major reasons for such anthropogenic migration stem from the induced ecological imbalances that humankind has created. This means that reclaiming health as a social common implies addressing the changes that we need to make in our developmental choices and behaviours as an integral part of the earth's ecosystem. We leave aside the worn-out war-metaphor in the taming of the virus, a stereotype largely abused already in the fight against HIV/Aids, which promotes a simplistic political narrative and makes no room for reasoning and coming up with alternatives. In line with what several authors in this journal highlight in their contributions, we prefer to consider the virus as a great teacher of sustainable development, an unprecedented source of knowledge not just about science and immunity, but especially about our collective priorities and values, in this new immunity paradigm. Boaventura De Sousa Santos appropriately engages us with the much more compelling metaphor of the virus-as-pedagogue

The only one that requires us to try and understand the virus and the underlying motives for its behaviour and, as a result, to try and organize social responses aimed at reducing the probability of being intruded upon in such an unwelcome way by future viruses (De Sousa Santos 2020).

SARS-CoV-2 is no doubt a brutal pedagogue, one that does not waste time explaining the reasons why it behaves the way it does. But it is not an irrational being-we are bound to realize this unequivocally as we are confronted with the second waves of the pandemic in Europe-which means that we'd better at this point set our minds and actions so that we try and align with it, humbly learning from the virus. As Pankaj Mishra put it, announcing a return of the big government, 'it has taken a disaster for the state to assume its original responsibility to protect citizens' (Mishra 2020). For more than three decades, or at least since the end of the Cold War, the grand infatuation has been obsessively seeded that the world was being knit together peaceably in a global journey to the promised land of civilization and human rights, led by the free market guidelines for capitalism, technology and democracy. In his 1996 State of the Union address, Bill Clinton announced that 'the era of big government is over' (Gonsalves and Kapczynski 2020: 20). In 2008, with Barack Obama's election, the United States seemed to have entered a post-racial age, even; ready to 'race for new frontiers' in 'the greatest time to be alive', as President Obama indulged in writing in Wired. ${ }^{3}$

The reality is that the global dynamics that have made COVID-19 so disruptive have deep roots in the political and social order defined by globalization, in the fact that 'words like democracy, freedom, justice, unity [...] have

\footnotetext{
3 https://ww.wired.com/2016/10/president-obama-guest-edits-wired -essays.
} 
been bent and shaped to serve as tools for domination, as meaningless tags that can be used to justify any action'. ${ }^{4}$ Globalization has rescaled distributional conflicts so that in the end they cannot be ultimately resolved within national borders. Globalization has also fuelled the power of transnational corporations and the ultra-rich, which has dramatically contributed to reducing national policy space (Shrecker 2019). Constraints are substantial and this is nowhere more apparent than in the structural features of healthcare and the public health sectors. One year of COVID-19 has finally clarified that the world remains adrift in the middle of the storm, heading towards an entirely different historical period under the guidance of weak divided leaderships.

International research has devoted increasing attention to the political and policy dynamics of health, but the approach to the global political economy of health remains piecemeal and grossly underdeveloped, while 'the deeper structural foundations of health governance and the basic drivers of global health outcomes are often obscured' (Sell and Williams 2019). With COVID-19, the re-routing of analysis towards a political economy of health and illness, so as to address the central engines in society that drive and sustain the production of health, or conversely the production of diseases, has all the contours of a difficult uphill exercise. One would imagine that with the new coronavirus still on the loose, research agendas that are focussed on the structural challenges and interconnections of the health-(in)security and health-(in)equality linkages have gained new meaning. Certainly, if we listened to the virus, that should be the case. Many of the root causes of climate change have also increased the risk of pandemics and, for example, the nexus between health and pollution has helped explain the gravity of COVID-19 morbidity and mortality in some parts of the world (Comunian et al. 2020). Empirical evidence has confirmed that COVID-19 and the climate crises are two facets of the same response to human aggression (Frankel 2020). Likewise, the COVID-19 outbreak has magnified the racial and colonial hierarchies that lie underneath the social, economic and political determinants of health vulnerability (Cohen 2020).

It is encouraging to notice that Richard Horton acknowledges that COVID-19 is not a pandemic, but as a syndemic, thereby stressing its social origins, and embracing a broader vision that encompasses education, employment, housing, food, and most importantly environment (Horton 2020). This is clearly the mounting evidence around the new coronavirus. It is very disappointing, on the other hand, that

\footnotetext{
${ }^{4}$ Pope Francis, Fratelli Tutti (Brothers All), Encyclical Letter of the Holy Father Francis on Fraternity and Social Friendship, para 14, http://www.vatican.va/content/francesco/en/encyclicals/documents/ papa-francesco_20201003_enciclica-fratelli-tutti.html.
}

multilateral institutions and the global health community should refrain from making this cognitive leap, preferring the comfort zone of pathology clusters. They pay their stubborn tribute to the as obsolete as ever narratives of diseasecontrol, feeling safe in that terrain of vertical economic management of health. But that is precisely a narrative rupture that our epistemic community must push within the United Nations system and elsewhere, at a time when COVID-19 comes as a major threat to the sustainable development agenda.

The primacy of biomedical approaches guarantees the hegemonic interference of giant corporate actors, which continue to play the game as owners of intangible commodities like financial products and intellectual property rights, without restraints. On the other hand, this reductionist model has irreversibly fractioned epidemiological identities and communities, which are yielded the same medicalized packages in a theoretically limitless choice of healthcare options, so that extracting surplus from the sick be secured. The policies that have undermined the development of national health systems in low and middle-income countries, and ushered the privatization and financialization of healthcare, are prescriptions that continue to be imposed by the World Bank. ${ }^{5}$ Governments keep outsourcing to private actors the responsibility of running entire welfare structures in the name of desirable containment goals (even during the pandemic). The privatization of the health agenda has been interiorized as a viable and pragmatic shortcut by a significant portion of civil society organizations unwilling, or unprepared, to tackle more cumbersome systemic approaches (Shrecker 2019: 29).

Nowhere more successfully than in the health domain has the market orthodoxy permeated the landscape, pioneering the route to institutional governance transformations at all levels, including the international one, whereby the classical nation-state multilateral authority has gradually been supplanted by a new multi-stakeholder governance arrangement based on volunteerism, aimed to

....redefine the international system as constituting a wider, multifaceted system of global cooperation in which intergovernmental legal frameworks and institutions are embedded as a core, but not the sole and sometimes not the most crucial, component (Gleckman 2018: 9).

\footnotetext{
5 Reference here is to the recent World Bank's 'Maximising Finance for Development' approach which insists on the priority role attributed to private finance in the sustainable development agenda, including in the healthcare delivery, as public finance is considered insufficient and inevitably a last resort, https://www.gi-escr.org/blog/ the-right-to-health-in-a-post-covid-19-context-learning-hard-lessons.
} 
While the virus has pedagogically made a mockery of quintessential neoliberal models in health, the issue of privatized systems in essential sectors like health, water, food, and the dismantling of public services appear to be untenable in the context of COVID-19. The values and tools of the market, enshrined in privatization, have several implications, since they not only produce an institutional transformation of governance, but also, and more fundamentally, a normative one. In her article 'Why Privatization is Wrong', Chiara Cordelli reminds us that:

What is ultimately wrong with privatization, then, is not-at least, not primarily-that it commodifies, thereby corrupting, the meaning, or nature, of some particular goods or purposes, nor that it makes the provision of certain public goods impossible. Nor is it only the fact that privatization may embody an objectionable form of neoliberal rationality, or that private actors tend to be motivated by inherently objectionable, profit-making considerations, or are unaccountable in the sense of lacking transparency or being unresponsive to the political community. The ultimate wrong of privatization rather consists in the creation of an institutional arrangement- the privatized state- that denies equal freedom, understood not as mere noninterference but rather as a relationship of reciprocal independence. It does so by making the definition and enforcement of individuals' rights and duties, as well as the determination of their respective spheres of freedom, systematically dependent on the merely unilateral will of private actors [...] Today, the ever-greater entanglement between public and private, brought about by processes of privatization since the late twentieth century, leads to a re-feudalization of the state itself-a collapse between public offices and private loyalties, status and contract-that undermines the very rationale that justifies the existence of the modern state and the exercise of political power by its government (Cordelli 2020).

COVID-19 itself does not escape this logic. In fact, the pandemic emergency risks exasperating this trend in the frantic competition for the breakthrough COVID-19 vaccines, with their ascertained legacy of stock markets euphoria (Pratley 2020). The fact is that drug development spurred by geopolitical whims or baseless enthusiasm generated by company press release will not serve the purpose. Without public evidence of what really works, and how, to control and stop the contagion, the huge risk is wasting unprecedented amounts of taxpayers' money to chase dead ends for the profits of the few, rather than expediting rigorous and appropriate medical research in the public interest of the many.

The SARS-CoV-2 pandemic has certainly debunked the inevitability of past misleading approaches, but a reset to more just and equitable social and economic outcomes will not happen by itself. The very return of the 'big government' may unlikely rise to the gigantic challenges ahead, actually, at least in the short term. New actionable policy approaches and continuous mobilization and education will have to be based on the lessons of the virus, 'a co-creation of humans and nature, a co-creation that is a product of the way in which men have interfered with natural processes' (De Sousa Santos 2020). Holistic choices are needed more than ever to tackle health problems and re-imagine health as a public good. Well beyond disease control. Well beyond this COVID-19 pandemic.

\section{Healthy Commons to Rebalance Power, Pursue Justice and Reaffirm Democracy}

The authors in this journal issue convey the same message, albeit from different analytical angles. The time for technical adjustments and tinkering is over. This is the time for a systemic change aimed at rebalancing power, pursuing social and environmental justice, and reaffirming democracy. As it has always happened with past epidemics, the social and economic effects of the COVID-19 outbreak are deepening inequalities and asymmetries, but this may be a time when the field acts as a force against inequalities, to demand a more direct protagonism. The persistence of institutionalized violence and racism even at the multilateral system needs to be addressed. ${ }^{6}$ Inequalities are the result of political choices, so they can removed by political choices. The question, as Jonathan Cohen puts it, is

whether changes in policy, practice and culture that seemed unthinkable before COVID-19, but which now appear within our grasp, will transform the social determinants of health in ways that promote genuine racial equity and global justice (Cohen 2020).

Could COVID-19 translate into the longed-for opportunity to concert concrete alternative strategies for a healthier future? How? We would like to inject new energy into this conversation, and mobilization. Health is a powerful metaphor. Health is also a viable trajectory in the journey towards freedom, democracy and human rights. It is an entry point for renewed policy options that may address the pathological outcomes of globalization. Our meaningful question is not how much progress as measured by global health indicators we can make, after COVID-19, but how much more we can achieve if the power asymmetries that feature global governance for health are rebalanced, or how much those

\footnotetext{
${ }^{6}$ https://www.theguardian.com/global-development/2020/jul/18/unchief-slams-myths-delusions-and-falsehoods-around-inequality.
} 
asymmetries may endanger and prevent future advancement. A deeper and strategic comprehension of the pathogenic structures and their governance implications can help fight the painful idolatry coming from the financial and economic systems. Enhancing the capacity to act by policymakers and especially by the communities and social movements that currently pay the highest price of the viral outbreak is an urgent priority. It will not necessarily be a simple journey, we are all aware. Resistance keeps coming from the powerful interests of the pre-COVID world; but as the teenager climate campaigners taking Norway's government back to court, to oppose its plan to open the Artic for oil drilling illustrate, ultimately these are the best artisans of the future healthy commons we want to see.

\section{References}

Azmanova, Albena. 2020. Capitalism on Edge: How Fighting Precarity Can Achieve Radical Change Without Crisis or Utopia. New York: Colombia University Press.

Cohen, Jonathan. 2020. A Time for Optimism? Decolonizing the Determinants of Health, Health and Human Rights Journal, 17 November, https://www.hhrjournal.org/2020/11/a-time-for-optim ism-decolonizing-the-determinants-of-health/.

Comunian, Silvia, Dario Dongo, Chiara Milani, and Paola Palestini. 2020. Air Pollution and CPVID-19: The Role of Particular Matter in the Spread and Increase of COVID-19 Morbidity and Mortality. International Journal of Environmental Research and Public Health 17 (12): 4487.

Cordelli, Chiara. 2020. Why Privatization Is Wrong, The Boston Review, 24 November, http://bostonreview.net/politics-philosophy -religion/chiara-cordelli-why-privatization-wrong.

De Sousa Santos, Boaventura. 2020. Metaphors in Progress, contribution for the seminar Questioning Corona, A Symposium on the Social Impact of the Virus, \#733, September, https://www.india -seminar.com/2020/733/733_boaventura_de_sousa.htm.
Di Cesare, Donatella. 2020. Virus sovrano? L'asfissia capitalista. Turin: Bollati Boringhieri.

Frankel, Jeffrey. 2020. COVID-19 and the climate crisis are part of the same battle, The Guardian, 2 October, https://www.theguardia n.com/business/2020/oct/02/covid-19-and-the-climate-crisis-arepart-of-the-same-battle.

Gleckman, Harris. 2018. Multistakeholder Governance and Democracy: A Global Challenge, Earthscan from Routledge.

Gonsalves, Gregg, and Amy Kapczynski. 2020. The New Politics of Care, in The Politics of Care: From COVID-19 to Black Lives Matter, August, Boston Review \& Verso Books.

Horton, Richard. 2020. Offline: COVID-19 is not a pandemic. The Lancet 396 (10255): 874.

Mishra, Pankaj. 2020. Coronavirus Will Revive an All-Powerful State, Bloomberg, 17 March. https://www.bloomberg.com/opinion/artic les/2020-03-17/coronavirus-will-revive-an-all-powerful-state.

Pratley, Nils. 2020. Covid vaccine is great for humanity—and not bad for the stock market either, The Guardian, 9 November, https:// www.theguardian.com/business/nils-pratley-on-finance/2020/ nov/09/a-great-day-for-humanity-and-not-bad-for-the-stock-marke t-either.

Sell, Susan K., and Owain D. Williams. 2019. Health under capitalism: a global political economy of structural pathogenesis, Review of International Political Economy, 9 September: 1-25. https:// www.tandfonline.com/doi/full/10.1080/09692290.2019.1659842.

Shrecker, Ted. 2019. Globalization and Health: Political Grand Challenges, Review of International Political Economy, July: 26-47, https://www.tandfonline.com/doi/full/10.1080/09692 290.2019 .1607768 .

Visvanathan, Shiv. 2020. The Problem, Contribution for the seminar Questioning Corona, A Symposium on the Social Impact of the Virus, \#733, September, https://www.india-semin ar.com/2020/733/733_the_problem.htm.

Publisher's Note Springer Nature remains neutral with regard to jurisdictional claims in published maps and institutional affiliations. 